\title{
DEMOCRATIC DEFICIT OF INVESTMENT ARBITRATION IN THE VIEW OF RULES ON TRANSPARENCY AND MAURITIUS CONVENTION ON TRANSPARENCY
}

\author{
Dominik Horodyski*
}

\begin{abstract}
This paper presents and analyzes the concept of transparency in investment arbitration, recognized by the UNCITRAL Rules on Transparency in Treaty-based Investor-State Arbitration and Mauritius Convention on Transparency in Treaty-based Investor-State Arbitration in the perspective of democratic principles of public participation, legitimacy and accountability. It holds that, transparency of investment arbitration endorsed by these documents constitutes a next step in the process of democratizing investment arbitration, contributes to the increase of democratic principles and cures the alleged democratic deficit of InvestorState arbitration.
\end{abstract}

INTRODUCTION 160

I. TRANSPARENCY IN INVESTOR-STATE ARBITRATION BEFORE UNCITRAL RULES ON TRANSPARENCY AND CONVENTION ON TRANSPARENCY ............. 162

A. ICSID Arbitration Rules ....................................................... 162

B. Commercial Arbitration Rules................................................. 163

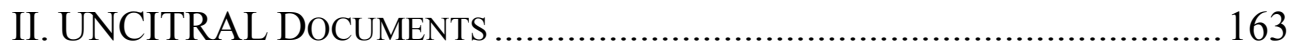

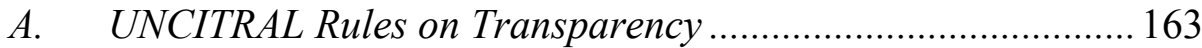

B. Mauritius Convention on Transparency ................................. 165

III. DEMOCRATIC PRINCIPLES IN INVESTMENT ARBITRATION ....................... 166

IV. RELATIONS BETWEEN DEMOCRATIC PRINCIPLES AND INVESTMENT

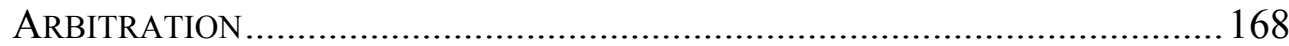

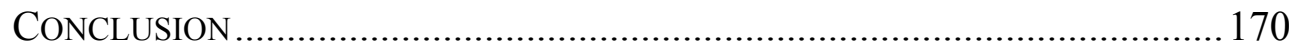

\section{INTRODUCTION}

Investment arbitration has been accused of lack of democratic principles for many years. ${ }^{1}$ Critics have argued that, due to globalization,

\footnotetext{
${ }^{*}$ Chair of Private Economic Law, Faculty of Law and Administration, Jagiellonian University. Research fields: investment arbitration, commercial arbitration, commercial law and civil law. ${ }^{1}$ Methanex Corporation v. United States of America, Decision of the Tribunal on Petitions from Third Persons to Intervene as "Amici Curiae", 22 (January 15, 2001). Available at http://www.italaw.com/sites/default/files/case-documents/ita0517_0.pdf. G. Kaufmann-Kohler, L'arbitrage D'investissement: Entre Contrat et Traité-Entre Intérêts Privés et Intérêt Public, 32 REVUe LibANAise D'ARBITRAGe 9-15 (2004). Available at http://www.lkk.com/data/document/arbitrage-investissement-entre-contrat-traite-entre-interets-prives-interet-
} 
there was diffuse of political national powers allowing it to be replaced by international systems and regulations. ${ }^{2}$ International decisions as to investment arbitration are made without the scrutiny of legislature or independent courts in camera by a selected group of private people and tend to favor private investors over the states. ${ }^{3}$ It makes the public participation or exercising the right to information almost illusory. Thus, investment arbitration is considered to lack accountability and legitimacy and provokes significant resistance. ${ }^{4}$

The remedy for deficit of democracy can be promoting transparency by introducing regulations, that enable to exercise democratic principles in the process of investment arbitration. ${ }^{5}$ This approach has already been taken by UNCITRAL in its two flagships elaborations: Rules on Transparency and Mauritius Convention on Transparency. These documents take the transparency approach; therefore, they grant effectiveness to the democratic principles like public participation, accountability and legitimacy. In addition, enhanced transparency can lift the veil of opacity from InvestorState disputes and strengthen credibility and fairness of arbitral tribunals' awards, which has direct impact on their acceptance in the society as well as confirms the rule of law, good governance, due process, fairness, equity and rights to access information. ${ }^{6}$

First part of the paper presents the current situation of transparency of investment arbitration based on most commonly applied arbitration rules to establish a background for further considerations. Then, the Rules on

public-i.e.pdf. OECD, Transparency and Third Party Participation in Investor-State Dispute Settlement Procedures, OECD WORKING PAPERs ON INTERNATIONAL InVESTMENT, 2005/01 (OECD Publishing 2005). Available at http://dx.doi.org/10.1787/524613550768.

${ }^{2}$ B. Choudhury, Recapturing Public Power: Is Investment Arbitration's Engagement of the Public Interest Contributing to the Democratic Deficit?, VANDERBILt Journal of TRANSNATIONAL Law 784 (2008). Available at SSRN: http://ssrn.com/abstract=1070701.

${ }^{3}$ N. Bernasconi-Osterwalder, Democratizing International Dispute Settlement: The Case of Trade and Investment Disputes, PAPER PRESENTED AT THE 6TH INTERNATIONAL CONFERENCE OF NEW OR RESTORED DEMOCRACIES 3 (Doha, October 29-November 1, 2006). Available at http://www.ciel.org/Publications/ICNRD6_300ct06.pdf.

${ }^{4}$ P. Eberhardt, \& C. Olivet, Profiting from Injustice How Law Firms, Arbitrators and Financiers are Fuelling an Investment Arbitration Boom, 71-3 (Brussels/Amsterdam, November 2012). Available at http://www.tni.org/sites/www.tni.org/files/download/profitingfrominjustice.pdf. Y. Fortier,

Arbitrating in the Age of Investment Treaty Disputes, UNSWLAWJL 14; 31(1) UNIVERSITY OF NEW SOUTH WALES LAW Journal 289-91 (2008). Available at http://www.unswlawjournal.unsw.edu.au/sites/default/files/14_fortier_2008.pdf.

${ }^{5}$ B. Choudhury, Recapturing Public Power: Is Investment Arbitration's Engagement of the Public Interest Contributing to the Democratic Deficit?, 784 VANDERBILT JOURNAL OF TRANSNATIONAL LAW 809-10 (2008).

${ }^{6}$ UNCITRAL Report of Working Group II (Arbitration and Conciliation) on the Work of Its FiftyThird Session, A/CN.9/712, 7 (Vienna, October 4-8, 2010). 
transparency as well as the Mauritius Convention on transparency are examined and reviewed to present the new solutions adopted by UNCITRAL. Next chapters concern the democratic principles of public participation, accountability and legitimacy associated with investment arbitration and their mutual relations.

\section{TRANSPARENCY IN INVESTOR-STATE ARBITRATION BEFORE UNCITRAL RULES ON TRANSPARENCY AND CONVENTION ON TRANSPARENCY}

\section{A. ICSID Arbitration Rules}

The most renowned rules and only one created particularly for investment disputes are the Arbitration Rules established by the International Centre for Settlement of Investment Disputes (ICSID) ${ }^{7}$. In spite of the fact that, they rely heavily on arbitration rules established for commercial disputes, the ICSID Arbitration Rules nevertheless distinguish itself in various ways as to their approach to transparency. ${ }^{8}$

The mechanisms adopted by ICSID Rules clearly show that, the confidentiality requirements are imposed more on the arbitrators and arbitral institutions than on parties. ${ }^{9}$ It suggests that, first, transparency which requires the parties' consent for publishing documents may be in fact illusory and does not grant real public access to documents-States and private investors may decide not to release documents to public, what they usually do ${ }^{10}$ and second, however, granting limited access to information as provided in ICSID Rules and Regulation is a step into right directions, it does not in fact let the public counter efficiently the democratic deficit associated with opacity of investment arbitration - the access to arbitration documents is still hindered and public participation is not provided at the

\footnotetext{
${ }^{7}$ The Rules of Procedure for Arbitration Proceedings (the Arbitration Rules) of ICSID were adopted by the Administrative Council of the Centre pursuant to Article 6(1)(c) of the ICSID Convention. The Arbitration Rules are supplemented by the Administrative and Financial Regulations of the Centre, in particular by Regulations 14-16, 22-31 and 34(1).

${ }^{8}$ K. Michałowska, Poufność Czy Jawność Międzynarodowego Arbitrażu Inwestycyjnego, PRzEGLĄD PRAWA HANDLOWEGO 56-7 (July 2009); For example, ICSID runs a Registry where data about cases is stored and ICSID, even without the parties' consent, may publish excerpts of final awards with a legal reasoning.

${ }^{9}$ L. Johnson, \& N. Bernasconi-Osterwalder, New UNCITRAL Arbitration Rules on Transparency: Application, Content and Next Steps, 6-7 (August 2013). Available at http://ccsi.columbia.edu/files/2014/04/UNCITRAL_Rules_on_Transparency_commentary_FINAL.pd f.

${ }^{10}$ Investors are concerned about their trade and professional secrets as well as about their reputation and financial position, while the States are not willing to show their vulnerability to investment arbitration and their submission to private investors as well as to arbitral tribunal awards.
} 
sufficient level. It is the consequence of the fact that, ICSID Arbitration Rules are much based on commercial arbitration rules and contain only traces of transparency's regulations, forced by the fact that, the second party to the dispute is always a State.

\section{B. Commercial Arbitration Rules}

Other arbitration rules that are used in investment disputes come from international organizations such as United Nation Commission on International Trade Law (UNCITRAL) or international commercial (business) institutions such as International Commercial Chamber in Paris (ICC), Stockholm Chamber of Commerce (SCC). These rules are primarily created to serve in commercial arbitration; therefore they contain modest regulation as to public access to proceedings and documents. They do not include mandatory publishing of documents but instead leave this issue to parties' decision. ${ }^{11}$ In addition, they restrict open hearings by allowing it only upon consent of both parties. ${ }^{12}$ As well as they do not regulate the third (non-disputing) party's submission to the arbitration. ${ }^{13}$

\section{UNCITRAL DOCUMENTS}

\section{A. UNCITRAL Rules on Transparency}

The United Nations Commission on International Trade Law (UNCITRAL) adopted Rules on Transparency in Treaty-based InvestorState Arbitration in July 2013. These rules came into effect on April 1, 2014, and established a new level of enhancing transparency in Investor-State treaty arbitration. ${ }^{14}$ They are said to implement arbitration rules that are

\footnotetext{
${ }^{11}$ L. Johnson, \& N. Bernasconi-Osterwalder, New UNCITRAL Arbitration Rules on Transparency: Application, Content and Next Steps, 7 (August 2013).

${ }^{12}$ Compare Art. 32 of ICSID Arbitration Rules, Art. 28 of UNCITRAL Arbitration Rules, Art. 26 of ICC Arbitration Rules, Art. 27 of SCC Arbitration Rules.

${ }^{13}$ However such submissions are nonetheless possible in specific situations relating to complex public and international law questions that emerge from the investment disputes, compare: E. Levine, Amicus Curiae in International Investment Arbitration: The Implications of an Increase in ThirdParty Participation, 29 BerKeley J. InT'L LAW 200, 209-10 (2011). Methanex Corporation v. United States of America, Decision of the Tribunal on Petitions from Third Persons to Intervene as "Amici Curiae”, 22 (January 15, 2001). Aguas Argentinas, SA, Suez, Sociedad General de Aguas de Barcelona, SA and Vivendi Universal, SA v. The Argentine Republic, ICSID Case No ARB/03/19, Order in Response to a Petition by Five NonGovernmental organizations for Permission to Make an Amicus Curiae Submission, 3 (February 12, 2007).

${ }^{14}$ Available at http://www.unis.unvienna.org/unis/en/pressrels/2014/unisl210.html. K. Michałowska, Zasady Dostępu Do Informacji o Postępowaniach Arbitrażowych w Sporach Inwestycyjnych (Project Zmian w Regulaminie Arbitrażowym UNCITRAL), PrZegląd PRAwa Handlowego, 9-12 (May
} 
usually applied in arbitration proceedings with provisions regulating issues relating to transparency matters. In the preamble, there were given major reasons justifying its adoption and presenting the goals that they are meant to achieve: the need for provisions on transparency to take account of the public interest involved in such arbitrations; the establishment of a harmonized legal framework for a fair and efficient settlement of international investment disputes; the increase of transparency and accountability and promotion of good governance. ${ }^{15}$ These aims were also at stake in early documents reporting the work of Working Group II of UNCITRAL on negotiating these rules. ${ }^{16}$

The content of the UNCITRAL Rules on transparency reflects the postulates as to granting decisive and explicit provisions mandating for the first time the transparency issues of investment arbitration. It has been done by providing three vast solutions aiming at introducing transparency into investment disputes. These solutions are: access to documents; third party's submissions and open hearings.

The access to documents is embodied in Art. 3, which contains a list of documents that must be disclosed. These documents are: the notice of arbitration, the response to the notice of arbitration, the statement of claim, the statement of defense and any further written statements or written submissions by any disputing party, as well as a table listing all exhibits (but not the content of the exhibits), transcripts of hearings, orders, decisions and awards of the arbitral tribunal should be made available to public. In addition, upon request, expert reports and witness statements should be also made public. As to exhibits and other documents not listed above, the arbitral tribunal disposes of certain discretion as to decide whether make them public or not. It should also be pointed out that, any broader disclosure requirements in the governing treaty will prevail in the event of any inconsistency between that treaty and the Rules on Transparency (Art. 1 (7)).

The non-disputing party's (amicus curiae) submissions regarding the matter within the scope of the dispute have also been granted. This right is expressly stated and provides detailed guidelines as to the procedure of

2013). A. Szumański, Poufność Czy Jawność Arbitrażu Inwestycyjnego, KsIĘGA JuBILEuszowa Profesora ANDRZeja Zolla, 916-22 (P. Kardas, T. Sroka, \& W. Wróbel eds, Warsaw 2012). J. Salasky, The New UNCITRAL Rules and Convention on Transparency, (August 6, 2014). Available at http://blogs.lse.ac.uk/investment-and-human-rights/portfolio-items/transparency-in-investment-treatyarbitration-and-the-un-guiding-principles-on-business-and-human-rights-the-new-uncitral-rules-andconvention-on-transparency/.

${ }^{15}$ Resolution adopted by the General Assembly on December 16, 2013 (on the report of the Sixth Committee (A/68/462)).

${ }^{16}$ UNCITRAL Report of Working Group II (Arbitration and Conciliation) on the Work of Its FiftyThird Session, A/CN.9/712, 7 (Vienna, October 4-8, 2010). 
submitting the statement of the third party (Art. 4). What is most important the third party's submission does not depend upon parties' consent, which means that, parties to the dispute, neither the state nor investor can block relevant statements coming from public voices of people directly affected by the investment.

Open hearings have been granted by Art. 6, which directly states that, for the presentation of evidence or for oral argument shall be public. It is another major change in contrast to other existing arbitration rules, which indicates different approach that must be taken when it comes to investment arbitration comparing to commercial disputes. Open hearings are subject to limitations, which are protection of confidential information and protection of the "integrity of the arbitral process". In addition, the arbitral tribunal has been obliged to make logistical arrangements to facilitate the public access to hearings. ${ }^{17}$

\section{B. Mauritius Convention on Transparency}

The major aim of the Convention is to provide an instrument for the application of the UNCITRAL Rules on transparency to the disputes arising under the existent investment treaties. ${ }^{18}$ Pursuant to Art. 1 (1) of the Convention, it applies to arbitration between an investor and a State concluded before April 1, 2014, which means that, it will cover all disputes arising from investment treaties, that fall outside the scope of Rules on transparency applied as a default rule to arbitration conducted under the UNCITRAL Arbitration Rules. It is pointed out that, the Convention sets out two ways for the Rules to apply to these existing treaties. First, as it is stipulated in Art. 2, the UNCITRAL Rules on transparency will apply to any Investor-State arbitration, whether or not initiated under the UNICTRAL Arbitration Rules, should the respondent and the State of the claimant be a Party to this Convention and have not made relevant reservations. Second option to make the Rules apply in case the Defendant State is a party to the

\footnotetext{
${ }^{17}$ L. Johnson, \& N. Bernasconi-Osterwalder, New UNCITRAL Arbitration Rules on Transparency: Application, Content and Next Steps, 6-7, 13-20 (August 2013); J. Salasky, The New UNCITRAL Rules and Convention on Transparency, (August 6, 2014).

${ }^{18}$ According to Art. 1 of the Rules on transparency, they shall apply to Investor-State arbitration initiated under the UNCITRAL Arbitration Rules pursuant to an investment treaty concluded on or after April 1, 2014, which means that, the thousands of cases resulting from existing treaties concluded before April 1, 2014 or initiated under other than UNCITRAL Arbitration Rules, would fall outside the scope of the Rules on transparency, compare: http://www.unis.unvienna.org/unis/en/pressrels/2014/unis1210.html; http://www.asil.org/blogs/uncitral-approves-draft-convention-transparency-treaty-based-investorState-arbitration-july.
} 
Convention, and has not made relevant reservations and the State of the claimant is not the party to the Convention is to obtain the consent from the claimant investor (Art. 2 (2)). ${ }^{19}$

The Convention provides mechanisms that help to establish transparency principle in vast majority of investment disputes resulting from existing thousands of bilateral investment treaties. Provided that, arbitration proceedings are conducted under different arbitration rules (ICSID, UNCITRAL, ICC, SCC), it was pertinent to introduce transparency into these proceedings to broaden the scope of application of the Rules on transparency. The Convention therefore will have major effect on harmonizing the practice of different arbitral proceedings all around the world, consisting in departing from confidentiality and establishing transparency as a mandatory default rule.

There are no doubts that, the Convention together with the Rules are milestones in amending Investor-State arbitration. ${ }^{20}$ Together they provide possibilities of eventually mandating transparency issues in all incoming disputes, and therefore they complement the process of establishing transparency as a default rule in all investment disputes that would be initiated in the future.

\section{DEMOCRATIC PRINCIPLES IN INVESTMENT ARBITRATION}

Apart from obvious interests of investors and States who are parties to the dispute, ${ }^{21}$ and thus are directly interested in how the dispute will be conducted, there is also a role of the public that comes into play and is often marginalized. This public interest is inevitably bound to exercising

\footnotetext{
${ }^{19}$ L. Johnson, The Transparency Rules and Transparency Convention: A Good Start and Model for Broader Reform in Investor-State Arbitration, 126 COLUMBIA FDI PERSPECTIVES 1-2 (July 21, 2014). Perspectives on topical foreign direct investment issues by the Columbia Center on Sustainable Investment. Available at http://ccsi.columbia.edu/files/2013/10/No-126-Johnson-FINAL1.pdf.

${ }^{20}$ L. Johnson, The Mauritius Convention on Transparency: Comments on the Treaty and Its Role in Increasing Transparency of Investor-State Arbitration, 19 (August 2013). Available at http://ccsi.columbia.edu/files/2013/08/Mauritius-Convention-Transparency-Paper-formattedFINAL.pdf.

${ }^{21}$ E. Neumayer, L Spess, Do Bilateral Investment Treaties Increase Foreign Direct Investment to Developing Countries?, 33(10) WORLD DeVELOPMENT 26-8. Available at http://eprints.lse.ac.uk/627/1/World Dev \%28BITs\%29.pdf; M. Jeżewski, Międzynarodowe Prawo Inwestycyjne, 137-38 (Warsaw 2011); P. Ochmann, Arbitraż Inwestycyjny Jako Gwarancja Bezpieczeństwa Inwestycji, W PoszUKIWANIU NOWEGo ŁadU EKONOMICZNEGO 183-90 (S. Owsiak, \& A. Pollock eds., Warsaw 2013); G. Van Harten, Arbitrator Behaviour in Asymmetrical Adjudication: An Empirical Study of Investment Treaty Arbitration, Osgoode Hall Law Journal, OsGoOde CLPE RESEARCH PAPER No. 41/2012, 33-48 (April 19, 2012). Available at http://ssrn.com/abstract=2149207; P. Eberhardt, \& C. Olivet, Profiting from Injustice How Law Firms, Arbitrators and Financiers are Fuelling an Investment Arbitration Boom, 23-9 (Brussels/Amsterdam, November 2012).
} 
democratic rights and is present in almost all State's actions performed in public sphere. ${ }^{22}$ It is argued that, the State is representing the interests of all society and hence is obliged to inform the citizens about its policies and activities also in regard to foreign investments. The investment arbitration engages always a State that disposes of public money (coming inter alia from national taxes), so the civil society has a right to control the actions of State's organs, especially in respect to investment disputes in which millions of dollars are at stake. If the State is defeated in such investment battle, it means the obligation to pay substantial amount of money, which affects adversely the State's budget and limits the money designed for exercising other policies. ${ }^{23}$ The results of careless or negligent investment policymaking may result in the collapse of government, dismissals of ministers and social unrest. Therefore, it is crucial to provide public access to investment arbitration to enable the public to control State's action and influence State's investment policy. The right to public access to such information is derived also from elementary human rights. ${ }^{24}$ It is underlined that, the lack of the possibility to exercise democratic rights as to access to information contributes to the negative atmosphere and criticisms of Investor-State arbitration as a fair method of settling investment dispute between foreign investors and States. In public opinion, often the arbitral tribunals are perceived to issue manifestly unjust final awards, which do not have justification in presented facts and are based on legal points of view of individual arbitrators. $^{25}$

Hence, the democratic values that are particularly exposed to investment arbitration are associated with transparency of State's actions. These principles are public participation, accountability and legitimacy. ${ }^{26}$

\footnotetext{
${ }^{22}$ E. Levine, Amicus Curiae in International Investment Arbitration: The Implications of an Increase in Third-Party Participation, 29 BERKELEY J. INT'L LAW 200, 206, 210-12 (2011).

${ }^{23}$ K. Michałowska, Poufność Czy Jawność Międzynarodowego Arbitrażu Inwestycyjnego, PRzEGLĄD Prawa Handlowego 54 (July 2009).

${ }^{24}$ A. Szumański, Poufność Czy Jawność Arbitrażu Inwestycyjnego, KsIĘGA JubILEUSzowA Profesora AndRZeJa Zolla 914 (P. Kardas, T. Sroka, \& W. Wróbel eds, Warsaw 2012).

${ }^{25} \mathrm{Ibidem}$, at 915 .

${ }^{26}$ Other issues related to democratic deficit that will not be discussed in this paper concern more general and broad questions, such as the relation between loss of States' sovereignty and international regulations, transferring law making process from national to international level, transferring the State's public power to international institutions, submission of States to arbitral tribunals' awards that may question laws properly adopted by State's parliament, to know more see: B. Choudhury, Recapturing Public Power: Is Investment Arbitration's Engagement of the Public Interest Contributing to the Democratic Deficit? 784 Vanderbilt Journal of Transnational LaW 777-8 (2008); M. Dziurda, \& C. Wiśniewski, Wplyw Umów BIT na Suwerenność Państw, PrzegląD Prawa HANDLOWEGO 15-8 (December 2013).
} 


\section{RELATIONS BETWEen DEMOCRATIC PRINCIPLES AND INVESTMENT ARBITRATION}

The lack of democratic principles such us public participation, accountability and legitimacy in the process of investment arbitration was common mainly due to the structure of arbitration rules that were crafted for commercial private disputes. As a result they did not include additional interests apart from the interests of the parties to the dispute, but also it was convenient for States to hide their activities by not making it subject to public scrutiny. Therefore, it was often difficult or impossible to obtain any information about the Investor-State arbitration. ${ }^{27}$ Neither the notice of the commencement of the settlement, the claimant's demands, arguments and official writings nor State's statements, legal reasoning, expert's opinions and final awards were released to public but instead kept in secret. ${ }^{28}$ In addition, the names of arbitrators were confidential and the hearings were held only in the presence of disputing parties in privacy. Another restriction in public participation concerned the formal lack of possibility of amicus curiae contributions. ${ }^{29}$

On the other side, the lack of transparency influenced directly the accountability of officials that were responsible for conducting investment disputes. Since the public has not known about investment disputes in which the State was involved, it could not take actions to control the State in this regard. Therefore, these confidentially of proceedings contributed to the decrease of reputation of investment arbitration as a fair method of settling investment disputes. In addition, the arbitral tribunal composed of private individuals raised concerns as to arbitrators' impartiality, and authorization to settle disputes that often related to serious matters affecting essential facilities, environmental issues or human rights. ${ }^{30}$

As a result, the opacity of investment arbitration in previous forms and its lack of transparency undermined the legitimacy of this method of settling

\footnotetext{
${ }^{27}$ N. Bernasconi-Osterwalder, Democratizing International Dispute Settlement: The Case of Trade and Investment Disputes, 3 PAPER PRESENTED AT THE 6TH INTERNATIONAL CONFERENCE OF NEW OR RESTORED DEMOCRACIES 1 (Doha, October 29-November 1, 2006).

${ }^{28}$ OECD, Transparency and Third Party Participation in Investor-State Dispute Settlement Procedures, OECD Working PAPERS On InTERnATIONAL InVESTMENT, 2005/01, 12 (OECD Publishing 2005).

${ }^{29}$ In recent years, in spite of formal absence of provisions in certain arbitration rules, there is a practice to accept amicus curiae contributions. It is also allowed under the ICSID Arbitration Rules, see: E. Levine, Amicus Curiae in International Investment Arbitration: The Implications of an Increase in Third-Party Participation, 29 BERKELEY J. INT'L LAW 200, 208-14 (2011).

${ }^{30}$ Y. Fortier, Arbitrating in the Age of Investment Treaty Disputes, UNSWLAWJL 14; 31(1) UNIVERSITY OF NEW SOUTH WALES LAW JOURNAL 283-9 (2008).
} 
investment disputes between investors and host States. ${ }^{31}$ The critics argue that, investors abuse their position given them by investment treaties and put their corporate profits before human rights and environmental issues of developing countries with critical social and economic situations. ${ }^{32}$ The arbitrators who appear in arbitral tribunals' panels are considered to be too strictly bound with law firms and to be unknown. ${ }^{33}$ In addition, contrary to any State's jurisdiction, their awards are final and not subject to appellate system, which makes the arbitral tribunal one-instance court operating in camera but unlikely to commercial arbitral tribunals the final awards of arbitral tribunals may and usually do influence not only disputing parties, but also lives and existence of thousands of people because they relate often to elementary public matters.

The voices arguing that, investment arbitration suffers from democratic deficit have already been raised. ${ }^{34}$ The authors claimed basically that, the main reason for this situation is the lack of transparency and public access to arbitration documents and hearings as well as lack of public participation. ${ }^{35}$ They postulated a reform to introduce more open approach to InvestorState arbitration as a panacea to current problems. In this context, presented in the first chapter description of existing regulations suggests that, certain steps towards transparency have been gradually taken by various international institutions (ICSID). It should also be noted that, there has been a change in the fashion of thinking about investment arbitration and a

\footnotetext{
${ }^{31}$ E. Levine, Amicus Curiae in International Investment Arbitration: The Implications of an Increase in Third-Party Participation, 29 BERKELEY J. INT'L LAW 200, 205-6 (2011).

${ }^{32}$ P. Eberhardt, \& C. Olivet, Profiting from Injustice How Law Firms, Arbitrators and Financiers are Fuelling an Investment Arbitration Boom, 7 (Brussels/Amsterdam, November 2012).

${ }^{33}$ G. Van Harten, Arbitrator Behaviour in Asymmetrical Adjudication: An Empirical Study of Investment Treaty Arbitration, 33-48 Osgoode Hall Law Journal, OSgOOde CLPE ReSEARCH PAPER No. 41/2012, 2-10 (April 19, 2012).

${ }^{34}$ B. Choudhury, Recapturing Public Power: Is Investment Arbitration's Engagement of the Public Interest Contributing to the Democratic Deficit?, 784 Vanderbilt Journal of Transnational Law 777-9 (2008); E. Levine, Amicus Curiae in International Investment Arbitration: The Implications of an Increase in Third-Party Participation, 29 BERKELEY J. INT'L LAW 200-201 (2011); Delivering Justice: Programme of Action to Strengthen the Rule of Law at the National and International Levels, REPORT OF THE SECRETARY-GENERAL (2012), A/66/749 after L. Johnson, \& N. BernasconiOsterwalder, New UNCITRAL Arbitration Rules on Transparency: Application, Content and Next Steps, 4, 6-7, (August 2013).

${ }^{35}$ B. Choudhury, Recapturing Public Power: Is Investment Arbitration's Engagement of the Public Interest Contributing to the Democratic Deficit?, 784 VANDERBilt Journal of Transnational LaW 830-2 (2008); E. Levine, A Amicus Curiae in International Investment Arbitration: The Implications of an Increase in Third-Party Participation, 29 BERKELEY J. INT'L LAW 200, 223-4 (2011); Y. Fortier, Arbitrating in the Age of Investment Treaty Disputes, UNSWLAWJL 14; 31(1) UNIVERSITY OF NEW SOUTH WALEs LaW JouRnal 290-1 (2008).
} 
move from almost total confidentiality to increasing openness. ${ }^{36}$ The recognition of democratic values that must be taken into consideration in relation to the public interest in ISDS, allowed acknowledging the need to introduce stronger and consistent regulation including mechanisms that lift the opacity veil and expose investment arbitration to public light and public scrutiny.

The recent UNCITRAL Rules on transparency and Mauritius Convention constitute a modern response to these allegations. They have met with common approval from various sources. Not only do the States, which are the key actors in this play, express their support towards its adoption but also international organizations, academics and practitioners appreciate their value in reforming investment arbitration. ${ }^{37}$ These positive opinions may suggest that, the Rules on transparency will be included in modern investment treaties, and will be used in disputes arising out of treaties concluded not only after but also before April 1,2014 as well as the number of states adhering to the Mauritius Convention will augment.

\section{CONCLUSION}

Despite no legal obstacles to transparency under the commercial rules, it is clear that, they have not opted for transparency and have not provided accessible entry for public to arbitration proceedings in general. In most cases, the decision as to making certain information or documents public has been dependent on parties' consent. That is why even specialized ICSID Rules, which grant a certain level of transparency (regardless from parties' intent) does not solve this problem because they answer only in limited scope to the calls for greater transparency in ISDS by providing merely basic information on: trends in investment law, States that are engaged in such disputes or legal reasoning from the final awards, but they do not provide sufficient public access to necessary information that could enable the public exercising democratic principles of public participation and control of State's actions. Therefore neither ICSID nor any other rules serve to public interest, which focuses not only on informing societies about investment disputes and their outcomes, but also on engaging them into investment disputes in direct manner.

The deficit of democratic principles was associated with the absence of

\footnotetext{
${ }^{36}$ Y. Fortier, Arbitrating in the Age of Investment Treaty Disputes, UNSWLAWJL 14; 31(1) UNIVERSITY OF NEW SOUTH WALES LAW JOURNAL 283-90 (2008).

${ }^{37}$ UNCITRAL Settlement of commercial disputes Transparency in treaty-based investor-State arbitration Compilation of comments by Governments Note by the Secretariat, A/CN.9/WG.II/WP.159/Add.1 to A/CN.9/WG.II/WP.159/Add.4.
} 
transparency regulations in investment arbitration. Commercial approach that was once taken was not sufficient, because it ignored the special position of Investor-State arbitration. Furthermore, it led to gradual mistrust of States and social groups towards investment arbitrators and this method of settling investments disputes in general.

UNCITRAL Rules on transparency have introduced a consistent regulation ${ }^{38}$ that was demanded, and needed to enlighten complex investment disputes and invite the public to take active part in settling them. The standards proposed by the Rules on transparency create mechanisms that allow public access to necessary information about the dispute itself, proceedings, arbitrators and final award. However, they go even further, because apart from the passive "right to know", they provide also the right to actively and efficiently participate in the proceedings in a form of open hearings and third party's submissions. Therefore, it may be concluded that, the Rules on transparency and subsequent Mauritius Convention will bring new quality in Investor-State arbitration as well as they will contribute to the increase of legitimacy of this method of settling investment disputes. ${ }^{39}$ The public will eventually have useful tools to take a closer look at the arbitration proceedings, control how the State is defending its cause as well as raise concerns by supplying arbitral tribunal with additional information, that may appear critical to decide the case or look at it from different perspective. All this may influence the method of operating of arbitral tribunals by putting emphasis more on public, social, environmental context of investment dispute than only on sophisticated, legal argumentation presented by private investors and defendant state. As a result, investment arbitration has a chance to earn better reputation and through public participation contribute to increase of democratic principles of accountability, and legitimacy of states involved into investment disputes in the public eyes.

\footnotetext{
${ }^{38}$ Nonetheless still susceptible to exclusion.

${ }^{39}$ Available at $\mathrm{http} / / \mathrm{hsfnotes} . c o m /$ publicinternationallaw/2013/07/18/uncitral-unveils-newtransparency-rules-for-investor-State-arbitrations-2/.
} 